\title{
Staffing of Organizations: Search Channels and Selection Tools
}

\author{
Borisova A.A. Snegirev V.A. ${ }^{*}$ Koval A.L. \\ Novosibirsk State Technical University, Novosibirsk, Russia \\ "Corresponding author. Email: snegirev.v93@mail.ru
}

\begin{abstract}
A research question has been posed on the speed of adjusting the control systems of domestic enterprises to changing the parameters and value requests of the labour subject. Challenges that enterprises are forced to overcome when organizing staffing in a highly competitive labor market are highlighted. The results of a survey $(\mathrm{N}=539)$ of specialists employed in the organisation are presented. Diagnostic tasks included assessment of used channels and identification of effective channels of job search; fixation of the applicants' suitability measures used during the professional selection of tools and diagnostic tools. The differences in the channels used to attract applicants belonging to different generational groups are determined. There was a slow change in the tools used by organisations to diagnose the professional suitability of applicants. Differences in the implementation of adaptation programs for new employees of organisations belonging to different age groups are indicated.
\end{abstract}

Keywords: staffing, search and attraction tools, professional selection tools, generation groups

\section{INTRODUCTION}

Organisations' approaches to the formation of staffing undergo significant changes. Several factors contribute to this. Firstly, in most professions and positions, a change in the labor market conditions and an increase in the imbalance between the demand and supply parameters are recorded. It becomes more difficult for employers to close vacancies and ensure high specialists' tightness $[8,10]$.

Secondly, there is a clear change in labor resources belonging to different generational groups. The share of specialists in older age groups belonging to the so-called generation $\mathrm{X}$ is significantly reduced, while the share of employees of generations $\mathrm{Y}$ who have other leading qualities and put forward new distinctive requests for organizing labour activities is expanding [11]. The change of generation groups and, as a result, the targeted requests of job seekers necessitates the adjustment of management systems and labour organisation to new requirements.

Thirdly, the procedures for staffing are actively equipped with automated tools aimed at reducing the resource provision for diagnosing professional suitability and making managerial decisions on applicants hiring. The introduction of tools changes the tactics of attracting and selecting targeted job seekers.

The transformation of approaches to staffing and instrumental equipment for their implementation raises the research question of the response and the readiness of management systems to work with other value preferences of specialists, to adapt diagnostic tools to the targeted requests of applicants. The author's hypothesis of the study is that the organisation of the personnel management systems of organisations is subject to the changing demands of generation $\mathrm{Y}$ applicants slowly and the tools used to attract, select and adapt do not fully reveal the value preferences of applicants.

These arguments and the hypothesis put forward determine the purpose, logic of the study and this article:

- firstly, we consider what search tools attracting job seekers, are used by enterprises to transform the labor market conditions from labor-surplus to labor-scarce;

- $\quad$ secondly, we determine whether there are differences in the channels and means of communication with applicants belonging to different generation groups;

- thirdly, we will talk about the dynamics of the approaches used to select and adapt new employees;

- finally, we will conclude if there is a change in the way employers communicate with applicants of different age groups and the applicable tactics for working with personnel in the labour-deficit market.

The results of the study and conclusions on the assessment of the employment of specialists of different age groups allow us to make a scientific statement: a gradual refusal to use universal means and tools for attracting, selecting applicants and their subsequent adaptation is recorded. Changes in value requests to the work of applicants 
(production (for example, Dalstam Group of Companies, AVEC CJSC, etc.), finance (Levoberezhny OJSC), trade (Lenta, Maria-ra, Leroy-Merlin), healthcare (Clinic No.16 of Novosibirsk), education (Novosibirsk State Technical University). Sample distribution (Table 1) shows:

- the breadth of the applicants of all ages coverage with a slight shift in the group from 16 to 27 years;

To identify the dynamics of approaches to the formation of personnel and instrumental equipment of the processes of attraction, selection and adaptation, a survey method of data collection was chosen. A questionnaire has been compiled with the following key indicators: differences in the employment channels of applicants belonging to different generation groups; differentiation of tools used by the employer during the selection procedures and adaptation programs for new employees [3].

The study involved 539 respondents working in organisations engaged in various types of activities observance of the equality of respondents according to the Gender criterion;

- the slight predominance in the sample of respondents with higher education.

These features of the sample impose a restriction on the subsequent interpretation of the research results and conclusions.

Table 1 Sample Distribution during the survey according to the criteria

\begin{tabular}{|c|c|c|c|c|c|c|}
\hline \multicolumn{7}{|c|}{ Criteria } \\
\hline Sample & Number of & Share in the & \multicolumn{2}{|c|}{ Gender, \% } & Education level & Share in \\
\hline \multicolumn{3}{|c|}{ age groups } & men & women & \multicolumn{2}{|l|}{ education } \\
\hline $\begin{array}{l}\text { under } 16 \text { years } \\
\text { old }\end{array}$ & 37 & 6.86 & 40.54 & 59.46 & average & 6.86 \\
\hline $\begin{array}{c}\text { 16-24 years } \\
\text { old }\end{array}$ & 127 & 23.56 & 46.46 & 53.54 & $\begin{array}{l}\text { secondary } \\
\text { vocational } \\
\text { education }\end{array}$ & 15.77 \\
\hline $\begin{array}{l}\text { 25-30 years } \\
\text { old }\end{array}$ & 65 & 12.06 & 40 & 60 & $\begin{array}{l}\text { incomplete higher } \\
\text { education }\end{array}$ & 15,58 \\
\hline $\begin{array}{l}\text { 31-35 years } \\
\text { old }\end{array}$ & 74 & 13.73 & 37.84 & 62.16 & $\begin{array}{l}\text { higher education - } \\
\text { bachelor }\end{array}$ & 23.01 \\
\hline $\begin{array}{l}\text { 36-40 years } \\
\text { old }\end{array}$ & 54 & 10.02 & 38.89 & 61.11 & $\begin{array}{l}\text { higher education - } \\
\text { specialty }\end{array}$ & 23.56 \\
\hline $\begin{array}{c}\text { 41-45 years } \\
\text { old } \\
\end{array}$ & 70 & 12,99 & 34.29 & 65.71 & $\begin{array}{l}\text { Higher Education - } \\
\text { master }\end{array}$ & 12,43 \\
\hline $\begin{array}{l}46-50 \text { years } \\
\text { old }\end{array}$ & 53 & 9.83 & 45.28 & 54.72 & postgraduate studies & 2.78 \\
\hline $\begin{array}{l}\text { over } 50 \text { years } \\
\text { old }\end{array}$ & 59 & 10.95 & 40.68 & 59.32 & - & - \\
\hline
\end{tabular}

\section{RESEARCH RESULTS. TOOLS FOR SEARCHING AND ATTRACTING APPLICANTS.}

The development of automated means of job search and attracting applicants is changing the ways and channels of employment. The most significant changes concern the expansion of communication methods, the acceleration of diagnostic procedures and the addition of functions to maintain the focus of attention of applicants to vacancies. Changes will continue in the future [1], as competition for employees intensifies.

According to experts' forecasts, in the near future, the need for direct contact between the applicant and the employer during search and selection can be minimized, because the big data technologies and the diagnostic tools of the digital footprint of users make it possible to accumulate information about the applicant and to conduct professional diagnostics in a preventive format (generating 
resumes and building a profile of the applicant [5]; initial selection by key diagnostic parameters, automation of analysis of the interaction with applicants incl. information support and interviews (Experium, 1996; Friendwork, 2012; Amazing Hiring, 2014; Potok, 2016; Robot Vera, 2017).

It can be expected that technology in the near future will significantly change the methods of communication and the employment channels used by applicants. In the present (according to the results of the authors' research), various measures of the demand for communication channels when searching for work are also recorded (Table 2).

The variety of applied job search channels reflects the activity of applicants and wide opportunities for building the interaction "employer-employee". Both external intermediary communication platforms (for example, work, specialized professional sites, job fairs) and the accumulated social capital of the applicant (networking, patronage, headhunting) are used [17].

Table 2 Frequency of using job search channels, \% of the number of choices

\begin{tabular}{|l|c|c|c|c|c|c|c|c|}
\hline \multirow{2}{*}{ Job search channel } & \multicolumn{7}{|c|}{ Age groups, years } \\
\cline { 2 - 10 } & $\begin{array}{c}\text { up to } \\
\mathbf{1 6}\end{array}$ & $\mathbf{1 6 - 2 4}$ & $\mathbf{2 5 - 3 0}$ & $\mathbf{3 1 - 3 5}$ & $\mathbf{3 6 - 4 0}$ & $\mathbf{4 1 - 4 5}$ & $\mathbf{4 6 - 5 0}$ & $\mathbf{5 0 +}$ \\
\hline social networks & 20.5 & 18.9 & 14.7 & 9,7 & 8.3 & 2.8 & 6.1 & 4,5 \\
\hline personal connections & 19.3 & 27.6 & 23.6 & 21,9 & 25.0 & 33.1 & 20.0 & 27.6 \\
\hline work sites & 18,2 & 17.6 & 17.8 & 19,4 & 12.1 & 11,9 & 9.1 & 8.9 \\
\hline professional sites & 14.8 & 4,8 & 7.6 & 9.2 & 9.9 & 9.9 & 7.3 & 2.2 \\
\hline media & 9.1 & 7.7 & 8.3 & 11,7 & 6.8 & 10.6 & 13.3 & 11.2 \\
\hline employment agencies & 5.7 & 1.3 & 2.6 & 4.6 & 3.8 & 6.3 & 10.3 & 4,5 \\
\hline forums & 4.6 & 1.3 & 1.9 & 1.5 & 0.8 & 0.7 & 0.6 & 2.2 \\
\hline organisation website & 3,4 & 5.1 & 7.0 & 5.1 & 6.8 & 4,2 & 5.5 & 5.2 \\
\hline job fairs & 3,4 & 1.6 & 0.6 & 1.0 & 3.0 & 2.8 & 1.8 & 2.9 \\
\hline educational institution & 1.1 & 5.8 & 5.7 & 5,6 & 7.6 & 3,5 & 10.9 & 8.2 \\
\hline patronage & - & 1.3 & 0.6 & 3.6 & 5,3 & 5,6 & 6,7 & 8.2 \\
\hline $\begin{array}{l}\text { HR-service itself went to the } \\
\text { applicant }\end{array}$ & - & 3.8 & 7.0 & 4.1 & 3.8 & 2.8 & 2.4 & 2.9 \\
\hline employment service & - & 2.6 & 1.9 & 2.6 & 6.1 & 5,6 & 6.1 & 10,5 \\
\hline $\begin{array}{l}\text { independent appeal to the } \\
\text { organisation }\end{array}$ & - & 0.6 & 0.6 & - & 0.8 & - & - & 0.8 \\
\hline
\end{tabular}

More than $50 \%$ of applicants of all age groups are employed through such channels as social networks, personal connections and work connections. At the same time, the differentiation of job search channels by applicants of different ages (belonging to different generational groups) is recorded.

Employment through work sites is no longer the undisputed leader among the channels used. Job seeking websites are most often used by applicants aged 25 to 40 (2nd place in the ranking of priority). In general, the frequency of use of social networks, professional specialized sites, personal connections and patronage is increasing [6].

For applicants of all age groups (with the exception of Generation Z), the predominant channel for job search is personal communication. Every fourth graduate of an educational institution starts his or her career due to family or friends. The use of the method is understandable since there are restrictions on the confirmation of a professionally formed potential and additional guarantees of the immediate environment are required to increase the chances of competitive employment.

Every third person who has crossed the 40-year milestone is also employed through the reputation capital formed in the family or among friends - personal connections. Using the channel in this situation allows reducing the cost of checking/confirming professional suitability due to accumulated assessments of the applicant's performance in other periods through a guarantee [7]. Therefore, the search for work in personal relations is applicable in situations of declining competitiveness of the applicant in relation to other players in the labor market.

With the accumulation of professional potential, commitment to the chosen field and functionality, the frequency of accessing specialized employment channels increases. Thus, applicants aged 31 to 45 years more often than others seek work through appeals to professional communities and groups.

Competitive advantages in the form of high efficiency and activity in mastering the professional competencies of employees in the age group from 25 to 31 provide more frequent cases of independent initiation of appeals to the 
employer (employment through the organisation's website) and response processes from HR managers.

It should be noted that the resource-intensive search channels for job seekers — job fairs, interaction with educational institutions - do not provide for the closure of a large number of job openings even for applicants of younger age groups, while low ratings of job performance through these channels are also recorded (Table 3) [12].

Table 3 Efficiency of employment channels used by applicants, \% of the number of choices

\begin{tabular}{|c|c|c|c|c|c|c|c|c|}
\hline \multirow[t]{2}{*}{ Job search channel } & \multicolumn{8}{|c|}{ Age groups } \\
\hline & $\begin{array}{l}\text { up to } \\
16\end{array}$ & $16-24$ & $25-30$ & 31-35 & $36-40$ & 41-45 & $46-50$ & $50+$ \\
\hline social networks & 26.0 & 14.4 & 9.4 & 6.9 & 4.6 & 2.2 & 7.6 & 2.3 \\
\hline personal connections & 30.0 & 37.2 & 30.2 & 33.0 & 32.9 & 44.2 & 29.6 & 42.1 \\
\hline work sites & 20.0 & 20.6 & 18.8 & 19.1 & 15.9 & 8.9 & 9.8 & 6.8 \\
\hline professional sites & 6.0 & 5.0 & 9.4 & 4.4 & 7.9 & 8.9 & 2.2 & 1.1 \\
\hline media & 6.0 & 4.4 & 5.2 & 9.6 & 5.7 & 11.1 & 8,7 & 9.1 \\
\hline employment agencies & 6.0 & 0.6 & 2.1 & 4.6 & 3,4 & 4.4 & 8,7 & 4.6 \\
\hline forums & - & 0.6 & 1.0 & 0.9 & - & - & 2.2 & - \\
\hline organisation website & 4,0 & 2.8 & 3.1 & 4.4 & 3,4 & 2.2 & 6.5 & 4.6 \\
\hline job fairs & - & 2.2 & - & 0.9 & 2.3 & 2.2 & - & 2.3 \\
\hline educational institution & - & 6,7 & 7.3 & 7.8 & 6.8 & 2.2 & 14,1 & 9.1 \\
\hline patronage & - & 1.1 & - & 4.4 & 10.2 & 5,6 & 5,4 & 9.1 \\
\hline $\begin{array}{l}\text { HR-service itself reached the } \\
\text { applicant }\end{array}$ & - & 1.7 & 9.4 & 4.4 & 3,4 & 5,6 & 3.3 & 2.3 \\
\hline employment service & - & 2.2 & 3.1 & 0.9 & 2.3 & 1.1 & 2.2 & 6.8 \\
\hline $\begin{array}{l}\text { independent appeal to the } \\
\text { organisation }\end{array}$ & - & 0.6 & 1.0 & - & 1.1 & 1.1 & - & - \\
\hline
\end{tabular}

In general, the most effective employment channels are personal and work ties. Many methods from the arsenal that the applicants have resorted to do not become effective. This situation indicates that the job search strategy is based on wide coverage of all possible options while maintaining a small number of effective channels on the market [16]. The breadth of coverage is associated with an increase in resource provision and causes the applicant to increase the cost of finding a job. At the same time, the stability of the return of only a limited number of channels is preserved.

Thus, the results of the use of job channels by applicants show, on the one hand, the expansion of the search field and means of communication with employers, and on the other hand, the preservation of the priority of productive channels - worksites and personal connections. This may indicate that the employer is moderate in developing new forms of interaction with target groups of applicants.

There is a differentiation of channels by age groups of applicants. The channel "personal connections" is more often used in situations of reduction/absence of competitive advantages among applicants (young specialists, employees over 40) [4]. Increasing competitive position and sustainability of professional choice (25-40) allows using highly specialized employment channels more often - it can be specialized forums and communities, organisation sites and response to the initiation of a request from the organisation.

It is possible that the employer's moderation in expanding the channels for closing vacancies and adjusting job applicants of different age groups to the targeted needs reflects the situation of a massive "pen" into the selection funnel with brutal subsequent filtering at the selection stages. Let us consider how organisations set their selection procedures and what tools are used to diagnose job applicants' professional suitability and job placement.

\section{DISCUSSION OF RESULTS. CHANGES IN THE USE OF DIAGNOSTICS OF PROFESSIONAL SUITABILITY OF SEARCHERS AND ADAPTATION OF SPECIALISTS.}

It was revealed that despite the variety of diagnostic tools presented in theory and practice $[2,13,14,15,18]$, organisations significantly differ in the frequency of application of instrumental support. Thus, to a greater extent, interviews are used at different levels of expertise (HR specialist, head of the structural unit and/or organisation). In general, these tools are used in almost half of the cases (Table 4). 
Table 4 Frequency of use of selection tools, in \% of the number of selections

\begin{tabular}{|c|c|c|c|c|c|c|c|c|}
\hline \multirow[t]{2}{*}{ Instruments } & \multicolumn{8}{|c|}{ Age groups, age } \\
\hline & $\begin{array}{c}\text { up to } \\
16\end{array}$ & $16-24$ & $\begin{array}{l}25- \\
30\end{array}$ & 31-35 & $36-40$ & $41-45$ & $46-50$ & $50+$ \\
\hline testing & 27.0 & 29.9 & 44.6 & 39.2 & 31.5 & 35,7 & 41.5 & 25,4 \\
\hline interview with the head of the unit & 27.0 & 35.4 & 53.8 & 52.7 & 50.0 & 40.0 & 47.2 & 40.7 \\
\hline $\begin{array}{c}\text { qualifying conversation with the head of the } \\
\text { organisation }\end{array}$ & 24,3 & 40.9 & 64.6 & 51.4 & 27.8 & 40.0 & 32.1 & 32,2 \\
\hline interview with an HR specialist & 21.6 & 36,2 & 44.6 & 41.9 & 38.9 & 34.3 & 47.2 & 23.7 \\
\hline questioning & 21.6 & 20.5 & 24.6 & 24,3 & 16.7 & 18.6 & 18.9 & 13,6 \\
\hline resume analysis & 18.9 & 37.0 & 49.2 & 51.4 & 46.3 & 27.1 & 41.5 & 27.1 \\
\hline medical checkup & 10,8 & 25,2 & 20.0 & 18.9 & 27.8 & 27.1 & 24.5 & 23.7 \\
\hline professional test & 10,8 & 22.0 & 23.1 & 20.3 & 18.5 & 10.0 & 22.6 & 16,9 \\
\hline alcohol/drug test & 5,4 & 2.4 & 3.1 & 2,7 & - & 8.6 & 1.9 & 6.8 \\
\hline business games & 2,7 & 7.9 & 4.6 & 8,1 & 5,6 & - & 5.7 & - \\
\hline recruitment agency ratings & 2,7 & - & 4.6 & 8,1 & - & 7.1 & 7.5 & 3,4 \\
\hline assessment center & 0.0 & 0.8 & 1.5 & - & 3.7 & 1,4 & - & 0.8 \\
\hline polygraph & 0.0 & 4.7 & 3.1 & 4.1 & 1.9 & 2.9 & 1.9 & 3,4 \\
\hline braintester interview & 0.0 & 0.8 & - & - & - & - & - & 3,4 \\
\hline stressful interview & 0.0 & 5.5 & 6.2 & 8,1 & 3.7 & 2.9 & 1.9 & 3,4 \\
\hline graphology & 0.0 & - & 1.5 & - & - & - & 3.8 & - \\
\hline others not listed & - & 3.1 & 1.5 & - & 1.9 & - & - & - \\
\hline $\begin{array}{l}\text { analysis of the tools used in the professional } \\
\text { not reveal significant changes in relation to ap } \\
\text { different age groups. The most common are } \\
\text { id resource-consuming) ways for the empl } \\
\text { eract with job seekers (interviews and intervie } \\
\text { her information through analyzing resum } \\
\text { estionnaires [9]. The frequency of distribution } \\
\text { automated diagnostic tools for professional st }\end{array}$ & $\begin{array}{l}\text { ction } \\
\text { icants } \\
\text { ntact } \\
\text { er to } \\
\text { ) and } \\
\text { and } \\
\text { new }\end{array}$ & & $\begin{array}{l}\text { hary se } \\
\text { e assist } \\
\text { sample } \\
\text { modera } \\
\text { ating o } \\
\text { nostics } \\
\text { iremen } \\
\text { profes } \\
\text { imulate } \\
\text { the em } \\
\text { loyees }\end{array}$ & $\begin{array}{l}\text { ection th } \\
\text { ants was } \\
\text { formed } \\
\text { ion of th } \\
\text { the in } \\
\text { of the } \\
\text { s of the } \\
\text { sional } \\
\text { social } \\
\text { loyer to } \\
\text { f older a }\end{array}$ & $\begin{array}{l}\text { rough in } \\
\text { tot wide } \\
\text { this stu } \\
\text { majori } \\
\text { trument } \\
\text { suitabilit } \\
\text { osition. } \\
\text { perience } \\
\text { apital le } \\
\text { implem }\end{array}$ & $\begin{array}{l}\text { eraction } \\
\text { dissem } \\
\text { y). It is } \\
\text { of emp } \\
\text { equipn } \\
\text { of the } \\
\text { of the } \\
d \text { to a d } \\
\text { nt adapt } \\
\text { (Table } 5\end{array}$ & $\begin{array}{l}\text { with cha } \\
\text { lated (ac } \\
\text { orth tall } \\
\text { byers in } \\
\text { ent of } \\
\text { applican } \\
\text { applicant } \\
\text { crease in } \\
\text { tion pro }\end{array}$ & $\begin{array}{l}\text { ots and } \\
\text { rding to } \\
\text { ig about } \\
\text { e active } \\
\text { initial } \\
\text { for the } \\
\text { and the } \\
\text { he need } \\
\text { ams for }\end{array}$ \\
\hline
\end{tabular}

Table 5 Frequency of candidates passing adaptation programs, in $\%$ of the number of elections

\begin{tabular}{|c|c|c|c|c|c|c|c|c|}
\hline \multirow{2}{*}{$\begin{array}{c}\text { Implementation of adaptation } \\
\text { programs }\end{array}$} & \multicolumn{9}{|c|}{ Age groups, years } \\
\cline { 2 - 9 } & $\begin{array}{c}\text { up to } \\
\mathbf{1 6}\end{array}$ & $\mathbf{1 6 - 2 4}$ & $\mathbf{2 5 - 3 0}$ & $\mathbf{3 1 - 3 5}$ & $\mathbf{3 6 - 4 0}$ & $\mathbf{4 1 - 4 5}$ & $\mathbf{4 6 - 5 0}$ & $\mathbf{5 0 +}$ \\
\hline carried out & 43,2 & 62,2 & 72.3 & 70.3 & 53.7 & 57.1 & 54.7 & 50.8 \\
\hline not carried out & 56.8 & 37.8 & 27.7 & 29.7 & 46.3 & 42.9 & 45.3 & 49.2 \\
\hline
\end{tabular}

Starting from the age group from 36 to 40 years, a recorded, while a relatively small variety of adaptation decrease in the frequency of use of adaptation programs is tools used is preserved (Table 6). 
Table 6 Tools used in implementing adaptation programs, $\%$ of the number of choices

\begin{tabular}{|l|c|c|c|c|c|c|c|c|}
\hline \multirow{2}{*}{ Instruments } & \multicolumn{7}{c|}{ Age groups, years } \\
\cline { 2 - 8 } & $\begin{array}{c}\text { up to } \\
\mathbf{1 6}\end{array}$ & $\mathbf{1 6 - 2 4}$ & $\mathbf{2 5 - 3 0}$ & $\mathbf{3 1 - 3 5}$ & $\mathbf{3 6 - 4 0}$ & $\mathbf{4 1 - 4 5}$ & $\mathbf{4 6 - 5 0}$ & $\mathbf{5 0 +}$ \\
\hline briefing & 33.3 & 22.0 & 18.9 & 16.7 & 18.6 & 25.7 & 19.2 & 22.0 \\
\hline counselling techniques & 20.5 & 16.5 & 17.3 & 13.9 & 16.1 & 13,2 & 16.2 & 17.1 \\
\hline $\begin{array}{l}\text { work } \\
\text { demonstration }\end{array}$ & 5.1 & 12,4 & 9.4 & 9.8 & 10.2 & 7.2 & 11.1 & 9.8 \\
\hline mentoring & 12,8 & 11.0 & 13,6 & 10.6 & 9.3 & 9.9 & 16.2 & 8,5 \\
\hline trainings & - & 5.2 & 5.2 & 6.9 & 9.3 & 9.2 & 3.0 & 7.3 \\
\hline lectures & 2.6 & 4.1 & 2.6 & 1.6 & 5.1 & 4,0 & - & 7.3 \\
\hline self study & 2.6 & 5.2 & 7.9 & 10.2 & 7.6 & 8.6 & 10.1 & 6.1 \\
\hline "leaving behind" & 2.6 & 5.2 & 2.6 & 3.7 & 1.7 & 5,3 & 3.0 & 3.7 \\
\hline participation in social projects & 2.6 & 1,4 & 1.6 & 2.0 & 2.5 & - & - & 3.7 \\
\hline business games & - & 2.1 & 2.6 & 1.2 & 0.9 & 1.3 & 3.0 & 2.4 \\
\hline discussions & 2.6 & 1.0 & 3.1 & 4.1 & 1.7 & 2.6 & 2.0 & 2.4 \\
\hline round tables & 5.1 & 0.7 & 1.6 & 1.6 & - & 2.0 & 1.0 & 2.4 \\
\hline harder job method & 5.1 & 3.8 & 3.1 & 4.1 & 4,2 & 2.6 & 4,0 & 2.4 \\
\hline educational films & - & 1.0 & 2.6 & 2.0 & 2.5 & 2.0 & 2.0 & 1.2 \\
\hline distance learning & - & 1,4 & 2.6 & 3.3 & 2.5 & 1.3 & 2.0 & 1.2 \\
\hline brainstorm & 2.6 & 3,4 & 0.5 & 3.3 & 1.7 & 1.3 & 1.0 & 1.2 \\
\hline $\begin{array}{l}\text { modelling/analysis } \\
\text { situations }\end{array}$ & 2.6 & 3.8 & 4.7 & 4.9 & 5,9 & 4,0 & 6.1 & 1.2 \\
\hline
\end{tabular}

For beginners and young employees, the frequency of passing adaptation programs is high. Here are a few reasons that explain the need for programs for applicants in the age group of 16 to 35 years.

Firstly, the greater mobility of such job seekers in the labour market and the variety of work organisation systems implemented in organisations. It should be noted that the diversity of organisations stimulates the mobility of applicants in the search for conditions for updating value requests to work. The change of employer necessitates the development of new distinctive regulations for the implementation of functional and corporate standards. Therefore, there is a need for organizing and implementing fairly fast schemes for the social and professional adaptation of new specialists.

Secondly, respondents noted the influence on the need for factor adaptation programs - a change in the direction of activity. The business's request for professional knowledge and skills is characterized by increased variability and forms a response from applicants for the development of new areas of professional knowledge and the mastery of new tools for implementing functionality. As a rule, specialists under 40 are more likely to decide to change their professional field and master new working methods; further, with age, the frequency decreases. Checking the conformity of the level of professionalism to the demand of the position and organisation, bringing it to the level of the norm is realized through adaptation programs.

Thirdly, employees at this age (from 16 to 35) are characterized by greater capacity for work, flexibility, openness to master new schemes of labour actions. Obtaining greater labour returns from specialists is based on reducing the time spent on "readjustment". Adaptation programs, in fact, are structured schemes of standards of social expected professional and organisational behaviour. Training on the rules of performing labour functions according to structured schemes reduces the cost of entering a post and speeds up the process of bringing an employee to the planned level of labour return.

\section{CONCLUSION}

A review of the employment practices of specialists in the regional labor market allows us to conclude:

- there is significant differentiation in the speed of development, introduction on the market of instrumental equipment for staffing and its testing and active use in the operational activities of organisations;

- a relatively small differentiation in the applied tools for attracting and communicating with applicants of different age groups is revealed; 
organizatsii / Panova A.G., Baurchulu T.S. // Servis v Rossii i za rubezhom. - 2017. - №3 (73). S. 149-161.

[9] Predlozheniye na rynke truda prevzoshlo spros / «Kommersant" FM». - [Elektronnyy resurs] - Rezhim dostupa: https://www.kommersant.ru/doc/4172877 (data obrashcheniya 20.10.2019).

Perhaps the speed and frequency of updating the arsenal of recruitment managers depend on the time and financial resources of the organisation. The data from the current study record a moderate rate of introducing new instrumental solutions into the practice of staffing organisations.

\section{ACKNOWLEDGMENT}

This work was financially supported by the Novosibirsk State Technical University (project C19-11)

\section{REFERENCES}

[1] Borisova A.A. Organizatsiya deyatel'nosti sluzhb upravleniya personalom (rossiyskaya praktika). Monografiya: monografiya / A. A. Borisova. Novosibirsk: Izd-vo NGTU, 2012. - 250 s.

[2] Bespal'ko V. A. Upravleniye chelovecheskimi resursami / Deyneka A.V., Bespal'ko V.A. M.:Dashkov i K, 2017. - 392 s.

[3] Garifullina A.F., Timirgalina V.V. Trudoustroystvo molodezhi v Rossiyskoy Federatsii // NovaInfo.Ru. 2015. - T.1. № 30. S. 367-369.

[4] Issledovaniye rynka truda i obzor zarabotnykh plat. Rossiya. 2019 / Rekrutingovaya kompaniya Antal. [Elektronnyy resurs] - Rezhim dostupa: https://antalrussia.ru/salary-survey/ (data obrashcheniya 10.11.2019)

[5] Kutayev SH.K. Trudoustroystvo bezrabotnykh: sostoyaniye i regional'nyye osobennosti // Voprosy strukturizatsii ekonomiki. 2019. № 2. S. 26-30.

[6] Nikishina A.L. Issledovaniye sovremennykh tekhnologiy podbora personala // Sovremennyye nauchnyye issledovaniya i innovatsii. 2016. № 7. [Elektronnyy resurs]. URL: http://web.snauka.ru/issues/ 2016/07/70081 (data obrashcheniya: 07.02.2019).

[7] Ozernikova T.G. Kadrovyye riski rossiyskikh universitetov // Trud i sotsial'nyye otnosheniya. - 2018. - № 3. S. 81-92.

[8] Panova A.G. Upravleniye talantami kak neobkhodimyy element strategii razvitiya personala
[10] Rudenko G.G. Poisk talantov i referal'nyye programmy / Rudenko G.G., Sidorova V.N., Sidorov N.V. // Vestnik OmGU. Seriya: Ekonomika. - 2018. №3. S. 143-148.

[11] Teoriya pokoleniy v rossiyskom menedzhmente. Luchshiye praktiki upravleniya raznovozrastnymi komandami: podbor, obucheniye, motivatsiya: monografiya / N.V. Samoukina. - Moskva: RUSAYNS, 2018. - $186 \mathrm{~s}$.

[12] Trosheva M.A., Lektorova YU.YU. Kontseptsiya privlekatel'nogo HR-brenda v soznanii potentsial'nykh sotrudnikov // Goroda i mestnyye soobshchestva. 2017. -T.2. S. 174-182.

[13] Chulanova O.L. Kadrovyy konsalting : uchebnik / O.L. Chulanova. M. : INFRA-M, 2018. 358 s.

[14] Herschberg, C. Precarious postdocs: A comparative study on recruitment and selection of early-career researchers / Herschberg, C., Benschop, Y ., Van Den Brink, M. // Scandinavian Journal Of Management. - 2018. -Vol. 34, No 4. P. 303-310.

[15] Liu, J.Y. What Caused the Shortage of Labour: Examining the Recruitment and Selection in the Internet Financial Industry in China / Liu, J.Y., Cai, Y.J. // Advances in Theory and Practice of Emerging Markets. - 2018. - P. 339-357.

[16] Oldham G.R., Cummings A. Employee Creativity: Personal and Contextual Factors at Work // Academy of Management Journal. - 1996. - № 39. - p. 607-634.

[17] Schepers P., Van den Berg T. Social Factors of Work-Environment Creativity // Journal of Business and Psychology. - 2007. - № 21. - p. 407-428.

[18] Woldman N. Supporting temporary agency workers' affective commitments: exploring the role of opportunities for competence development/ $\mathrm{N}$. Woldman, R. Wesselink, P. Runhaar \& M. Mulder // Human Resource Development International. - 2018. Vol.21, No 3. P. 254-275. 